\title{
Studies on the recent epidemiology of early syphilis in West London
}

\author{
M. A. WAUGH \\ Department of Venereology, West London Hospital, Charing Cross Group of Hospitals
}

In recent years there has been increasing awareness of the part played by homosexual behaviour in the spread of venereal diseases. No doubt some European countries, their laws being based on the Napoleonic Code of 1810, in which questions of fornication and homosexuality were left to the conscience of the individual (West, 1968), had early recognized the phenomenon of variations from heterosexual conduct. Indeed Hecht (1957) mentioned that he had been teaching on 'Normal and pathological sexual life' and 'Sexual pedagogics', at Prague as early as 1926. However, it was not until the second world war led to a disruption of regular patterns of life and morality, and the moving around of many young men, that Anglo-Saxon countries began to acknowledge the part played in the spread of venereal disease by homosexual intercourse. Hinrichsen (1944) wrote a comprehensive paper about the importance of knowledge of sexual habits in the diagnosis and control of venereal disease with special reference to homosexual behaviour. This covered most aspects of homosexually acquired venereal disease in the United States of America and Europe up to that date and included a bibliography. In Great Britain Harkness (1948) once more drew attention to the fact that gonorrhoea, syphilis, and lymphogranuloma inguinale frequently involved the rectum and anal canal.

Macdonald (1949) pointed out that a certain amount of sympathy and understanding was needed for a patient to admit he had acquired an infection by homosexual intercourse. Macdonald also drew attention to the tendency of homosexuals to gravitate towards London. This observation was supported by Jefferiss (1956) who showed that in London a significant proportion of male venereal disease patients were homosexuals.

Since then the Report of the Committee on Homosexual Offences and Prostitution, 1957 (The Wolf-

Received for publication April 6, 1972

Paper read at a Meeting of the M.S.S.V.D. in London on October 27, 1972 enden Report) has been presented to Parliament and, after prolonged discussion and debate, its recommendations regarding homosexuality reached the statute book on July 27, 1967. As Morton (1971) stated, venereologists certainly have the impression that the number of men admitting a homosexual source of infection has increased. The number of infected homosexuals who are now prepared to name their sex contacts and co-operate in achieving their attendance for treatment has also risen. The recommendations of the Wolfenden Report have most certainly brought a refreshing change from the venereologist's point of view. Indeed, in this study, 64 (37.2 per cent.) of 172 exclusively homosexual patients with early syphilis were seen as a result of a sex contact also attending. If allowance is made for syphilis contracted outside the United Kingdom, this is most heartening.

Since April, 1963, an active campaign has been carried on to encourage homosexuals to attend the department of venereology at the West London Hospital (Fluker, 1966). A similar campaign was instituted at Basel by Schuppli (1962), who stated that 12 to 15 per cent. of fresh syphilis in Zürich had been acquired homosexually, this at a time when the level of early syphilis in Europe was low. Schuppli had the full support of the civil authorities, and homosexuals were informed where they could attend for investigation. Schuppli (1968) reported the success of the campaign.

\section{Aims of present study}

The purpose of this study was not only to show that the assumptions and observations made in the last decade on the epidemiology of syphilis in homosexuals were still true, but also to compare the epidemiology with that seen in the same period amongst other clinic patients with syphilis.

\section{Clinical method and materials}

A prospective study was made of all patients attending with early acquired syphilis in the 2 years January 1,1970 , to December 31, 1971. Patients in whom the initial diagnosis had been made at other centres but who subsequently 
attended for treatment were excluded, but patients in whom the diagnosis was made at the West London Hospital but attended elsewhere for treatment were included. Early syphilis is defined here as primary, secondary, and latent in the first 2 years of infection, as in the returns given each quarter since 1971 to the Department of Health and Social Security.

Throughout the period of the survey the standard serological tests for syphilis used at the West London Hospital have been the cardiolipin Wassermann reaction (CWR), the Venereal Disease Research Laboratory (VDRL) slide test, and the Reiter protein complementfixation (RPCF) test, augmented on numerous occasions by the absorbed fluorescent treponemal antibody (FTAABS) test, which was performed at the Venereal Disease Reference Laboratory at the London Hospital.

\section{Results}

A total of 33,866 new cases $(20,928$ males and 12,938 females) were seen in the department of venereology during the 2 years of this study. Altogether 259 had early syphilis, of whom 226 were male and 33 female, giving a male to female ratio of $6 \cdot 8: 1$, similar to the figure of $6 \cdot 6: 1$ given for London in 1969 by the British Co-operative Clinical Group (1970).

Early syphilis contributes only a very small proportion of the new cases seen, $1 \cdot 1$ per cent. for men and 0.3 per cent. for women, but if homosexuals only are considered, the proportion is greater.

During the study 3,400 new male homosexual patients were seen, of whom 1,337 had gonorrhoea; of these 630 were urethral and 707 rectal infections, the difference possibly being explained by the fact that some other men with urethral infection were unwilling to admit the homosexual source of their infection. The ratio of early syphilis to gonorrhoea in homosexuals was 1:7.172 cases of early syphilis (5.1 per cent.) were seen amongst the exclusively homosexual patients. Because many homosexuals presented with multiple infections, the importance of syphilis in this group was even more apparent. Oriel (1971) showed that the situation was much the same elsewhere in London. In a period of 9 months at St. Thomas's Hospital, 27 (6 per cent.) of the white homosexuals had primary syphilis.

If bisexuals, who in this series all acquired syphilis from a homosexual contact, are included, $190(84 \cdot 1$ per cent.) of the cases of early syphilis seen in men were contracted homosexually (Table I). Woodcock (1971) gave the figure of 68.5 per cent., including homosexuals and bisexuals, for a series studied in 19681969 at St. Mary's Hospital, London.

\section{Age range (Figure)}

The patients' ages ranged from 15 to 60 years; heterosexual men 17 to 53 (mean $27 \cdot 4$ ); bisexual men
TABLE I Cases of early syphilis in men, fan. 1, 1970, to Dec. 31, 1971

\begin{tabular}{|c|c|c|}
\hline Type & No. of men & $\begin{array}{l}\text { Cases of early syphilis } \\
\text { (per cent. of total) }\end{array}$ \\
\hline Homosexual & 172 & $76 \cdot 1$ \\
\hline Bisexual & 18 & $8 \cdot 0$ \\
\hline Heterosexual & 36 & 15.9 \\
\hline Total & 226 & $100 \cdot 0$ \\
\hline
\end{tabular}
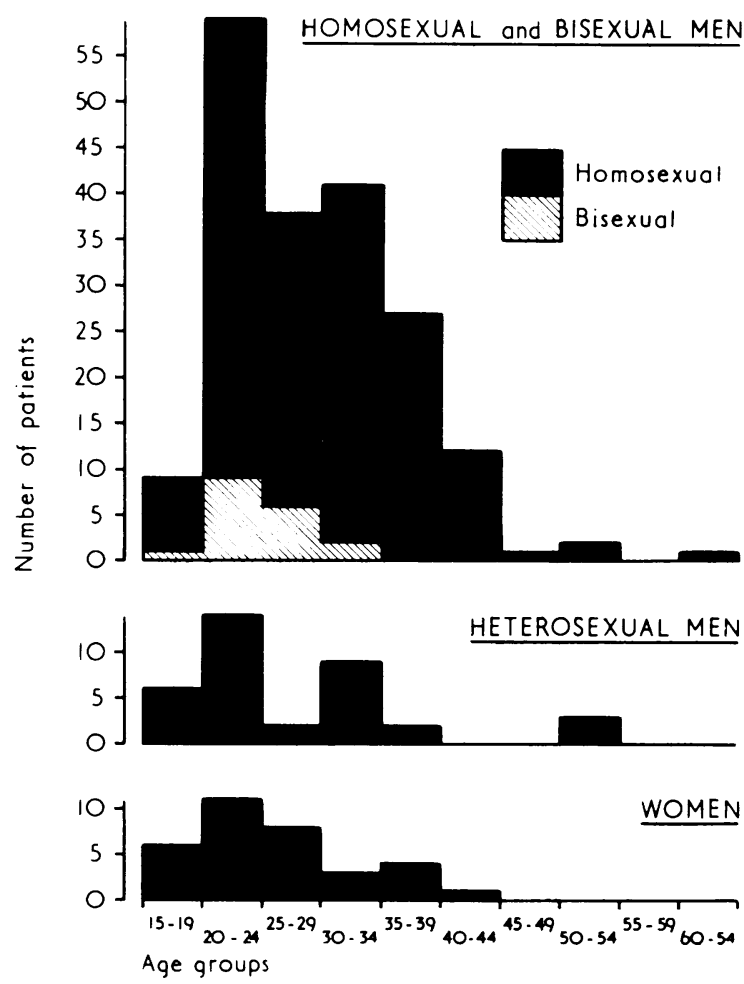

FIGURE Age distribution of patients with syphilis

19 to 32 (mean 24.6); homosexual men 15 to 60 (mean 29.5); women 15 to 41 (mean $25 \cdot 5$ ).

\section{Occupation (Table II, overleaf)}

Despite the social changes in employment since Jefferiss (1956) published his paper, it was found that his Occupation Table still acted as a useful framework for classifying employment. He noticed a predominance of clerks, shop assistants, waiters, and those employed in artistic callings. In the present study many hairdressers and air stewards were also seen. There were many more professional men (14 per cent.), including not only members of the three 
TABLE II Occupations of homosexuals and heterosexuals with early syphilis

\begin{tabular}{|c|c|c|c|c|c|c|}
\hline \multirow[t]{2}{*}{ Series } & \multicolumn{3}{|l|}{$\begin{array}{l}216 \text { homosexuals } \\
\text { at St. Mary's } \\
\text { (after Fefferiss, 1956) }\end{array}$} & \multicolumn{2}{|c|}{$\begin{array}{l}172 \text { homosexuals and } 18 \\
\text { bisexuals (Total 190) } \\
\text { West London Hospital (1970-71) }\end{array}$} & \multirow{2}{*}{$\begin{array}{l}36 \text { heterosexuals } \\
\text { West London Hospital } \\
(1970-71) \\
\text { No. }\end{array}$} \\
\hline & & No. & Per cent. & No. & Per cent. & \\
\hline \multirow[t]{4}{*}{ Occupation } & $\begin{array}{l}\text { Unskilled indoor } \\
\text { Artistic } \\
\text { Semi-skilled manual }\end{array}$ & $\begin{array}{l}98 \\
40 \\
25\end{array}$ & $\begin{array}{l}45 \cdot 6 \\
18 \cdot 5 \\
11 \cdot 6\end{array}$ & $\begin{array}{l}69 \\
25 \\
33\end{array}$ & $\begin{array}{l}36 \\
13 \\
17\end{array}$ & $\begin{array}{l}7 \\
3 \\
2\end{array}$ \\
\hline & $\begin{array}{l}\text { Artisan } \\
\text { Student } \\
\text { Out of work }\end{array}$ & $\begin{array}{r}17 \\
17 \\
7\end{array}$ & $\begin{array}{l}8 \cdot 0 \\
8 \cdot 0 \\
3 \cdot 0\end{array}$ & $\begin{array}{r}17 \\
14 \\
5\end{array}$ & $\begin{array}{l}9 \\
7 \\
3\end{array}$ & $\begin{array}{r}12 \\
4 \\
7\end{array}$ \\
\hline & Armed forces & 5 & $2 \cdot 0$ & 0 & - & 1 \\
\hline & $\begin{array}{l}\text { Schoolboy } \\
\text { Retired }\end{array}$ & 7 & $3 \cdot 0$ & 27 & 14 & 0 \\
\hline
\end{tabular}

senior professions (Church, Law, and Medicine) but many school teachers and social workers. On their first visit patients were asked to give their occupation by the receptionist. The answer given often proved incorrect on further questioning by the physician. This was seen most often among patients in skilled employment; two examples were a solicitor and film director who initially stated that they were clerks. In general the occupations of the homosexual men were not unlike those reported from Hungary by Racz (1970).

A comparison was also made with heterosexual men attending with early syphilis. No professional men were seen, but there was a preponderance of artisans, perhaps because of the high proportion of patients of Caribbean and Indian origin in this group. The abolition of National Service means that very few servicemen are now seen in civilian clinics.

\section{Marital status (This is shown in Table III)}

\section{Country of origin (Table IV, opposite)}

There were more homosexuals ( 73 per cent.) born in the British Isles than heterosexuals (59 per cent.). Amongst heterosexuals, West Indians (22 per cent.) formed a large part of the remainder.
Sexual preference in homosexuals

Amongst 172 homosexuals, 35 (20.4 per cent.) were exclusively active and 62 (36 per cent.) usually passive, while 75 (43.6 per cent.) were versatile. This information was not always obtained when the patient first attended with syphilis, but was gathered at previous and subsequent attendances for different infections, homosexual patients being frequent repeaters.

Amongst eighteen bisexuals, eight were active, six passive, and four versatile in their homosexual activity.

\section{Previous venereal infection}

This was often difficult to assess with accuracy unless the patient had always attended the same clinic. Such patients often visit different clinics in the metropolis, especially those who are frequently infected. Nevertheless Table V (opposite) gives some idea of past history of syphilis and gonorrhoea.

Stage of syphilis and site of chancre (Table VI, opposite)

In this study darkfield positive chancres were found only on the penis, anus, or anal margin. No chancres were found at other extra-genital sites. In some cases treponemes were demonstrated in serum obtained from anal condylomata lata.

TABLE III Marital status of patients with early syphilis

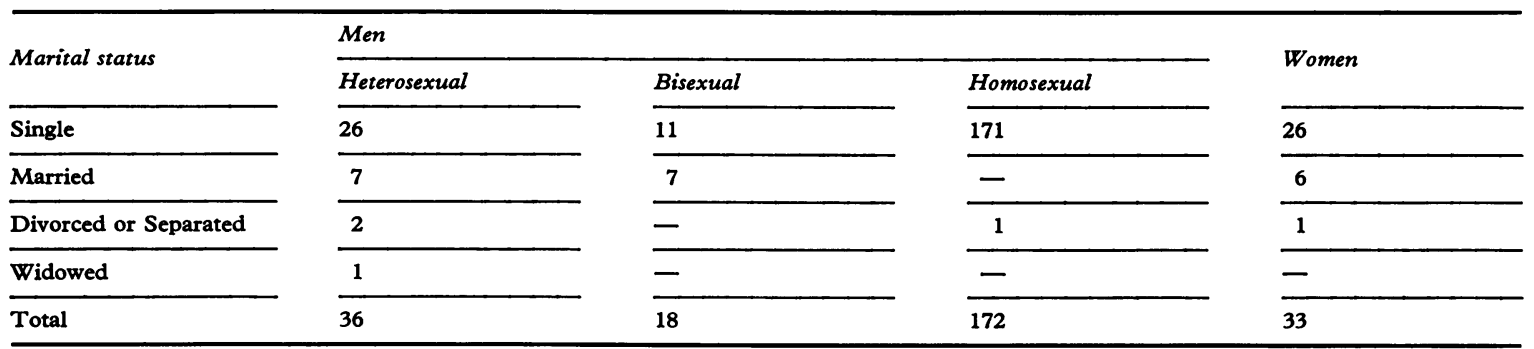


TABLE IV Country of origin of patients with early syphilis

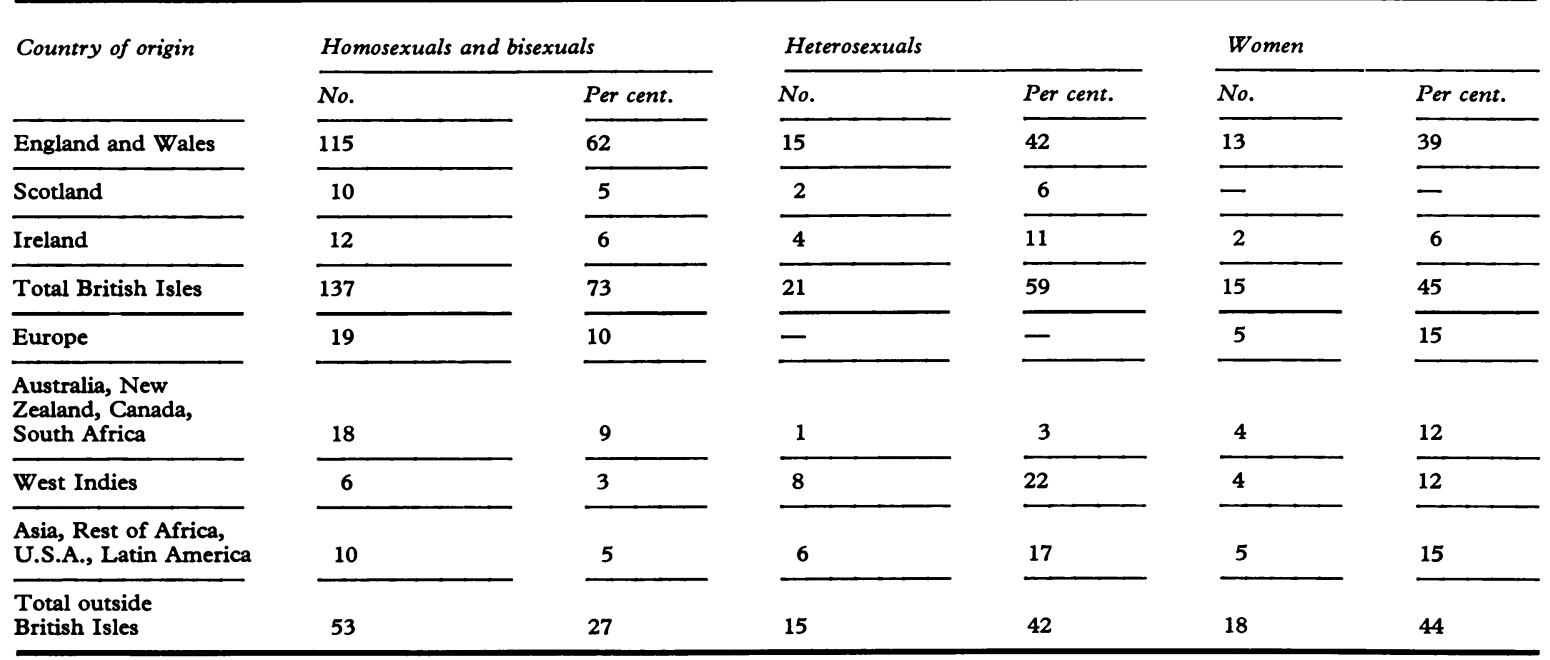

TABLE V Previous history of at least one episode of syphilis or gonorrhoea not including concurrent infection

\begin{tabular}{llll}
\hline Diagnosis & $\begin{array}{l}\text { Homosexual } \\
(172)\end{array}$ & $\begin{array}{l}\text { Bisexual } \\
(18)\end{array}$ & $\begin{array}{l}\text { Heterosexual } \\
(36)\end{array}$ \\
\cline { 1 - 3 } & $\frac{3}{3}$ & $\frac{1}{2}$ & $\frac{2}{3}$ \\
\hline Gonorrhoea & 75 & 3 & 3 \\
\hline
\end{tabular}

\section{Multiple infection}

Syphilis was often found in combination with other conditions such as gonorrhoea, or other sexually transmitted infections (non-specific urethritis, scabies, pediculosis pubis, or condylomata acuminata). Amongst 36 heterosexuals, two also had gonorrhoea and two had other conditions. Amongst eighteen bisexuals, one also had pediculosis pubis. But amonst 172 homosexuals, 52 (30 per cent.) had multiple infections (44 gonorrhoea and eight other conditions).

\section{Recent antibiotics}

Woodcock (1971) and Schroeter, Turner, Lucas, and Brown (1971) have shown that the present treatment of gonorrhoea with large intramuscular doses of penicillin is likely to abort incubating syphilis acquired at the same time. For this reason a note was made of

TABLE VI Stage of syphilis and site of darkfield positive chancres

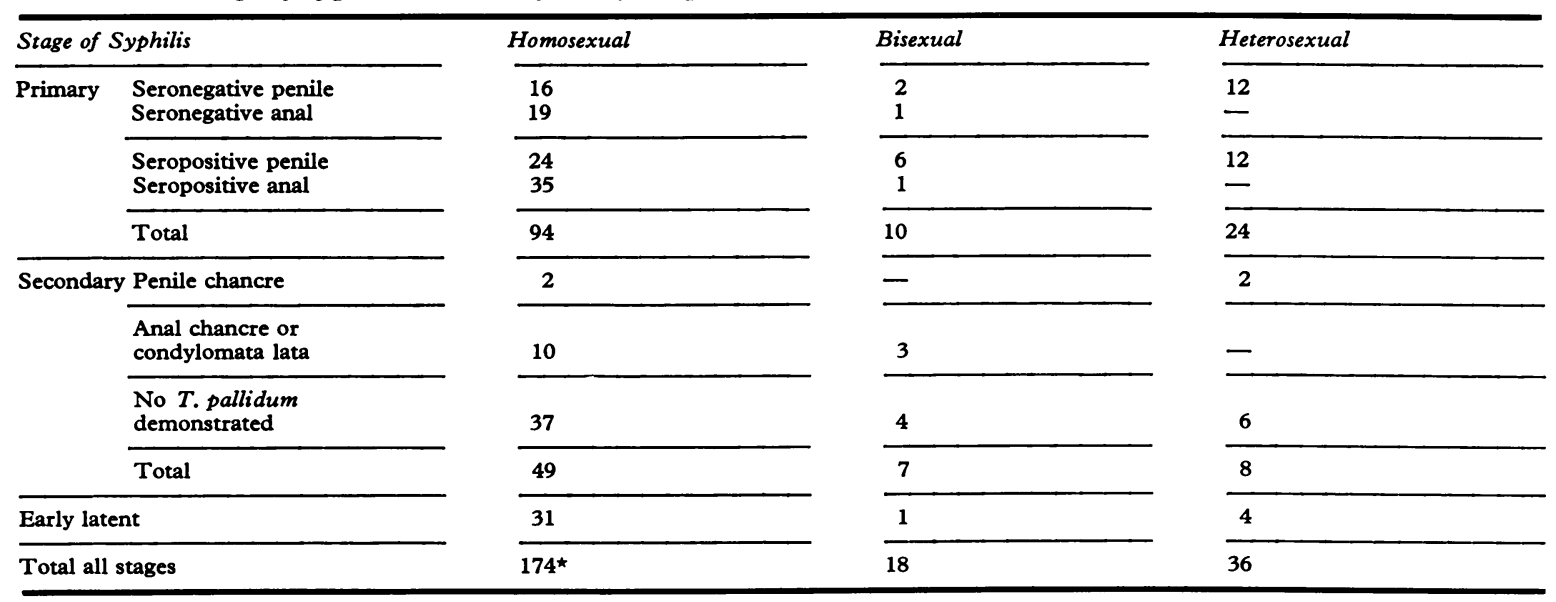

*In two cases a penile chancre and anal condylomata lata were both seen in the same patient; treponemes were found in both lesions 
recent antibiotic treatment. In fact, every new patient attending the venereology department is always asked if he or she has recently been given antibiotics or chemotherapeutic agents. Only four patients, all homosexual, had been given a large dose of penicillin within the previous 3 months as therapy for gonorrhoea (1.8 mega units procaine penicillin intramuscular), and they all admitted to subsequent sexual activity. Two homosexuals were taking oral antibiotics, one for acne rosacea (tetracycline $250 \mathrm{mg}$. twice daily) and the other for rheumatic heart disease (erythromycin $250 \mathrm{mg}$. twice daily). In addition, one other homosexual patient with early latent syphilis had been given oxytetracycline $250 \mathrm{mg}$. four times daily for 5 days by a private doctor 2 months before, for what in retrospect was seen to be secondary syphilis.

Nine homosexual patients had received trimethoprim-sulphamethoxazole (Septrin) for the treatment of rectal gonorrhoea in the previous 3 months and had subsequently developed syphilis. A description of seven of these cases was given by Waugh (1971).

\section{Contacts (Table VII)}

Perhaps through lack of sympathy and adequate history taking, contact tracing in cases of homosexually acquired syphilis has been regarded as a difficult task, not likely to be very rewarding in bringing partners to a clinic. Factors contributing to the high incidence of infectious syphilis were described in considerable detail by Hooker (1964) in a group of 253 homosexuals in Los Angeles; the difficulty of contact tracing in a homosexual group was explained, with its meeting places in bars, parks, beaches, and streets, and its many brief temporary encounters.

In the course of the present study, 102 exclusively homosexual partners were seen as a result of contact tracing and 64 of them were found to be infected. The group in which the results from contact tracing were poor, was that of bisexual men with early syphilis. A well-orientated homosexual usually knows where to find his contact, even if the only clue is a telephone number or last weekend's club, but most of the bi- sexuals' homosexual activity studied in this series appeared to occur anonymously-Wilde's 'nostalgie de la boue'.

\section{Location of infection (Table VIII)}

Early infectious syphilis in the United Kingdom has been stated (British Co-operative Clinical Group, 1970) to be concentrated in London and the larger urban areas. The figures from the West London Hospital exemplify this finding. Homosexuals, prostitutes, migrants, and itinerant workers tend to be promiscuous groups and thus likely to contact venereal disease (Lancet, 1964; British Medical fournal, 1967). Nicol (1971) has shown that homosexuals are often well to do and may be widely travelled. Of the homosexual patients, 23 (13.5 per cent.) had contracted early syphilis outside the United Kingdom, eleven in Europe, four in the United States of America and Canada, four in North Africa, two in South Africa, and one each in Australia and Brazil. Ten of these were in artistic occupations (actor, musician, film director), five in the professions, and four in personal employment (air and ship's stewards); two were students, and two were clerks. These findings confirm those of Nicol. Of course, there are also no family ties.

TABLE VIII Location of infection

\begin{tabular}{|c|c|c|c|}
\hline Series & Heterosexual & Bisexual & Homosexual \\
\hline Greater London & 29 & 16 & 145 \\
\hline $\begin{array}{l}\text { United Kingdom } \\
\text { outside London }\end{array}$ & 4 & 1 & 4 \\
\hline Outside United Kingdom & 3 & 1 & 23 \\
\hline Total & 36 & 18 & 172 \\
\hline
\end{tabular}

\section{Syphilis in women}

\section{PROSTITUTION}

Amongst heterosexual men only 5 (14 per cent.) whose ages ranged from $30-53$ gave a prostitute as a source of infection. Indeed only 5 prostitutes were

TABLE VII Contacts examined and cases of syphilis discovered

\begin{tabular}{|c|c|c|c|c|c|c|}
\hline \multirow[b]{2}{*}{ Series } & \multicolumn{2}{|c|}{ West London Hospital } & \multicolumn{2}{|c|}{ Other hospitals } & \multicolumn{2}{|c|}{ All centres } \\
\hline & Contacts & $\begin{array}{c}\text { Diagnosis of } \\
\text { syphilis }\end{array}$ & Conttacts & $\begin{array}{c}\text { Diagnosis of } \\
\text { syphilis }\end{array}$ & $\begin{array}{l}\text { Total } \\
\text { contacts }\end{array}$ & $\begin{array}{l}\text { Total } \\
\text { diagnosed as } \\
\text { syphilis }\end{array}$ \\
\hline Heterosexual & 18 & 10 & 1 & - & 19 & 10 \\
\hline Bisexual Female contacts & 11 & 2 & - & - & 11 & 2 \\
\hline Male contacts & 3 & 1 & - & - & 3 & 1 \\
\hline Homosexual & 84 & 51 & 18 & 13 & 102 & 64 \\
\hline
\end{tabular}


seen with early syphilis during the time of this study; none of them admitted to this occupation, but were known to be prostitutes by experienced members of the staff. However, these 5 patients had previously no less than 3 episodes of syphilis and 17 of gonorrhoea between them.

\section{OTHER OCCUPATIONS}

The occupations of the remaining women, whose ages ranged from 15 to 41 , mean 25.5 (see Figure), were clerical, unskilled factory worker, or shop assistant 12, professional (S.R.N., teaching) 4, housewife 4, domestic servant 3, entertainment 2, and student, schoolgirl, and vagrant 1 each.

\section{TYPE OF INFECTION}

Of the 33 women with early syphilis, eleven had primary syphilis, twelve secondary syphilis, and ten early latent syphilis. Chancres were found in ten cases, (4 labial, 3 cervical, and 1 clitoris, 1 posterior fourchette, and 1 anal margin).

The incidence of syphilis in women remains at a very low level in West London.

\section{Discussion}

Since the report by Jefferiss in 1956 on the high incidence of syphilis amongst homosexual men, it has become evident that early syphilis in London and to a lesser degree outside the capital is to a large extent homosexually contracted. In this study $84 \cdot 1$ per cent. of early syphilis was so acquired. Jefferiss reported that 8.4 per cent. of 1,000 male patients suffering from early syphilis or gonorrhoea who attended consecutively at St. Mary's Hospital, Paddington in 1954, admitted recent homosexual contact. By 1961, 81 (72 per cent.) of 113 men suffering from early syphilis had acquired the disease homosexually (Jefferiss, 1966). Other authorities in London give differing figures, but the percentage of homosexually acquired syphilis seems to be greater on the West side of London, partly because there are more homosexual clubs and meeting places, and partly because the residential accommodation in such areas as Earls Court, Kensington, Notting Hill, and Paddington consists of flats and rooms rather than family houses.

Another factor which may bring more homosexual patients to some clinics than others is the attitude of clinic staff. As Fluker (1966) stated, 'Apart from downright unpleasantness, nothing is more likely to discourage attendance than either barely concealed disgust or a well-meant sermon'.

King (1962) noted that five (14 per cent.) of 35 men attending the London Hospital with early syphilis admitted homosexual contact. Nicol (1960) found that, of 57 men suffering from early syphilis who attended at St. Thomas's and St. Bartholomew's Hospitals during 1959, eighteen (32 per cent.) had contracted the disease by homosexual exposure. Figures more akin to those found in the present study were noted by Mascall (1961) at St. Peter's and St. Paul's Hospital in the West End of London, where 53 (79 per cent.) of 67 men had acquired syphilis homosexually. Fluker (1966), at the West London Hospital, reported that in the first quarter of 1965 thirty (73 per cent.) of those suffering from infectious syphilis were homosexual. Laird (1962) at Manchester, in the period 1957-1961, found that seventeen (27 per cent.) of 62 male patients with early syphilis had been infected by homosexual contact.

The trend towards homosexually acquired syphilis continues in Western Europe. Hartmann (1955) stated that one-third of the syphilis contacts resident in the city of Copenhagen were homosexuals, some of them being male prostitutes. Schmidt, Hauge, and Schønning (1963) found that a quarter of 52 males with early syphilis attending the Rudolph Bergh Hospital in Copenhagen in 1961 were homosexuals. Bijkerk (1970) noted that 84 (38 per cent.) of 224 Dutch males with early syphilis had acquired the infection homosexually during a period ending 1967. Laugier, Hunziker, Orusco, Brun, Grand, Maillard, Bauquis, and Posternak (1971) considered homosexuality to be a more important factor than prostitution in the spread of syphilis in Geneva in 1969-70 and showed that 11.9 per cent. of the total patients (male and female) seen at the university clinic were male homosexuals. Elsewhere authorities in countries with a predominantly European cultural background give varying figures for syphilis acquired homosexually. Adams (1967) stated that only 2 per cent. of cases of syphilis in Sydney were homosexually acquired. Platts (1969), in Christchurch, New Zealand, stated that about 6 per cent. of the venereal disease patients seen by physicians were homosexuals.

The west coast of Canada and United States of America has a well organized homosexual subculture and this is reflected in the figures on syphilis. Kanee and Hunt (1951) drew attention to the fact that in Vancouver eleven (57 per cent.) of nineteen men with early syphilis were infected homosexually. In Los Angeles (Tarr and Lugar, 1960), of 194 patients with infectious syphilis, 170 (87.6 per cent.) were males; of the 159 men who revealed the identity of their sexual partners, 89 (56 per cent.) had only male contacts, whilst 21 (13.2 per cent.) had both male and female contacts. Elsewhere in the United States of America, similar findings are reported. 
Trice and Clark (1961) stated that 57 per cent. of male patients with syphilis attending a clinic in Richmond, Virginia, were homosexual.

\section{Conclusion}

In this series of patients seen at the West London Hospital with early syphilis, of 226 men, 172 (76.1 per cent.) were exclusively homosexual; eighteen (8 per cent.) were bisexual but had contracted the infection by homosexual actions. The figures are of the same order as those found at other clinics in the western districts of London and no doubt reflect an overall national trend in the epidemiology of cases of early syphilis.

The age range of acquisition of early syphilis was found to be wider in homosexuals than in heterosexuals. The types of employment were much the same as those found by Jefferiss (1956), but more professional men (14 per cent.) were seen. Promiscuity was demonstrated by the high incidence of previous sexually transmitted and concomitant infections. The observation of Nicol (1971) of worldwide travel in homosexuals as a cause of sexually transmitted infection was exemplified by the number (13.5 per cent.) who contracted syphilis outside the United Kingdom.

Contact tracing has been successful and resulted in the attendance of 102 contacts of those who were exclusively homosexual; 64 of these were found to be infected.

Very few men who resort to prostitutes in London acquire syphilis. Syphilis remains rare in women.

\section{Summary}

The recent epidemiology of early syphilis in West London is discussed with regard to age range, occupation, marital status, country of origin, sexual preference, previous infection, stage of early syphilis, multiple infection, recent antibiotic therapy, contacts, and locality of infection.

At the West London Hospital $84 \cdot 1$ per cent. of patients in whom early syphilis was diagnosed in 1970 and 1971 were either exclusively homosexual or bisexual. The findings are compared with those at other centres and in other countries.

I should like to thank Dr. J. L. Fluker (Director, Department of Venereology, Charing Cross Group of Hospitals) for permission to use case notes of patients in his care, and for his constant help and encouragement. I should also like to thank Dr. J. D. Oriel, Consultant Venereologist, for his constructive criticism whilst preparing this paper, and Mr. J. Noble, M.B.E., F.I.T.V. Clinic Supervisor, who has so faithfully kept records of patients attending with early syphilis.

\section{References}

Adams, A. (1967) Med. F. Aust., 1, 145

BIJKERK, H. (1970) Brit. f. vener. Dis., 46, 247

British Co-operative Clinical Group (1970) Ibid., 46, 477

British Medical fournal (1967) Leader, 2, 5

FluKer, J. L. (1966) Brit. F. vener. Dis., 42, 48

Harkness, A. H. (1948) Proc. roy. Soc. Med., 41, 476

HartmanN, G. (1955) 'An Epidemiological Study of the Import of Syphilis into, Diffusion within, and Export from a Major Seaport, Copenhagen'. WHO/VDT 137 WHO, Geneva

Нвснт, H. (1957) Acta derm.-venereol. (Stockh.), 37, 182

HinRICHSEN, J. (1944) Urol. cutan. Rev., 48, 469

HookeR, E. (1964) 'Male Homosexual Life Styles and Venereal Disease', in 'Proceedings of the World Forum on Syphilis and Other Treponematoses', Public Health Service Publication No. 997, p. 431. U.S. Government Printing Office, Washington, D.C.

JEFFERISS, F. J. G. (1956) Brit. F. vener. Dis., 32, 17

- (1966) Ibid., 42, 46

KANEE, B., and Hunt, C. L. (1951) Canad. med. Ass. F., 65,138

KING, A. J. (1962) Proc. roy. Soc. Med., 55, 869

LAIRD, S. M. (1962) Brit. F. vener. Dis., 38, 82

Lancet (1964) Leader, 1, 481

LAUGier, P., Hunziker, N., OrusCo, M., BRUN, R., GRand, M.-L., Maillard, C., Bauquis, R., and Posternak, F. (1971) Praxis (Bern), 60, 1628

Macdonald, F. G. (1949) Brit. F. vener. Dis., 25, 13

MASCALL, N. (1961) Brit. med. F., 1, 899

MoRToN, R. S. (1971) 'Sexual Freedom and Venereal Disease', p. 72. Owen, London

Nicol, C. S. (1960) Practitioner, 184, 345 (1971) Hlth Trends, 3, 18

ORIEL, J. D. (1971) Brit. F. vener. Dis., 47, 373

Platts, W. M. (1969) Ibid., 45, 61

RACZ, I. (1970) Ibid., 46, 117

RePORT OF the COMmitTEe on Homosexual OfFences and Prostitution (Wolfenden Report) (1957) Cmnd. 247. H.M.S.O. London

Schmidt, H., HaUge, L., and SchønNING, L. (1963) Brit. F. vener. Dis., 39, 264

SCHROETER, A. L., TURNER, R. H., LuCAS, J. B., and BROWN, W. J. (1971) f. Amer. med. Ass., 218, 711

SchUPPLI, R. (1962) Dermatologica (Basel), 124, 155

- (1968) Praxis (Bern), 57, 1368

TARR, J. D. F., and LUGAR, R. R. (1960) Calif. Med., 93, 35

Trice, E. R., and Clark, F. A., Jr. (1961) Sth. med. F., 54,76

WAUGH, M. A. (1971) 'Trimethoprim-sulphamethoxazole (Septrin) in the treatment of rectal gonorrhoea illustrating its non-treponemicidal properties'. Paper read at meeting of M.S.S.V.D., October 29, 1971, London

WeST, D. J. (1968) 'Homosexuality', 2nd ed., p. 73. Penguin Books, Harmondsworth

Woodcock, K. R. (1971) Brit. F. vener. Dis., 47, 95 
Étude sur la récente épidémiologie de syphilis précoce dans la partie occidentale de Londres

\section{SOMMAIRE}

On discute la récente épidémie de syphilis précoce du 'West London' en fonction de l'âge, du métier, de la situation conjugale, du pays d'origine, des habitudes sexuelles, d'une infection antérieure, du stade de la syphilis précoce, d'infection répétée, d'une récente thérapeutique antibiotique, des contacts et du lieu de l'infection.

$\mathrm{Au}$ West London Hospital, 84,1 pour cent des malades chez lesquels une syphilis précoce fut reconnue en 1970 et 1971, étaient soit des homosexuels exclusifs, soit des bi-sexuels. Ces résultats sont comparés avec ceux d'autres centres ou d'autres pays. 